\title{
Water Sorption Isotherm Characteristics of Seeds of Six Indigenous Forest Tree Species in Ghana
}

\author{
J. M. Asomaning ${ }^{1}$, Moctar Sacande ${ }^{2}$ and Nana S. Olympio ${ }^{3}$ \\ ${ }^{\prime}$ Forestry Research Institute of Ghana (FORIG), University Post Office, Box 63, Kumasi, \\ Ghana.E-mail:joemirekuaso@yahoo.co.uk \\ ${ }^{2}$ Seed Conservation Department, Royal Botanic Gardens, Kew, Wakehurst Place, Ardingly, \\ WestSussexRH17 6TN, United Kingdom.E-mail:m.sacande@kew.org \\ ${ }^{3}$ Department of Horticulture, Faculty of Agriculture, Kwame Nkrumah University of Science \\ and Technology, Kumasi, Ghana. E-mail:nayasoly@yahoo.com
}

\begin{abstract}
The relationship between storage temperature, relative humidity and seed water content was investigated for six indigenous forest tree seed species, namely Garcinia kola, Terminalia superba, Terminalia ivorensis, Mansonia altissima, Entandrophragma angolense and Khaya anthotheca in Ghana. Seeds were equilibrated over a series of lithium chloride solutions with relative humidities ranging from 12 to $93 \%$ and silica gel with relative humidity of $3 \%$ at $20^{\circ} \mathrm{C}$. Seeds reached equilibrium with different days depending on seed size and structure, ranging from 13 days for E. angolense to 91 days for G. kola. When seeds equilibrated, moisture contents were determined gravimetrically, and values of moisture contents were then plotted against relative humidity to construct moisture sorption isotherms for the species. Seeds of T. superba, T. ivorensis, M. altissima, E. angolense and K. anthotheca, exhibited a sigmoidal relationship between seed water content and relative humidity indicative of three regions of water binding. Contrarily to other reports, the shape of the isotherm curve for G. kola - a desiccation sensitive species - also showed the reversed sigmoid pattern similar to isotherm curves of orthodox species rather than the monotonic shape. The isotherms showed that seed moisture content increased with increasing relative humidity. Seed samples of G. kola, placed at all relative humidities chambers, lost water(desorption) as the initial water content of $58 \%$ was very high and, therefore, possessed a higher water potential than the environments. Seeds of the other species either lost water (desorption) to the relative humidity chambers, or absorbed water from the chambers depending on the relative humidity of the environment they were placed.
\end{abstract}

\section{Introduction}

Seed water content is crucial to long-term survival of stored seeds, as it affects the rate of metabolic and deteriorative reactions (Vertucci \& Roos, 1990). There appears to be critical water content level above and below which seed ageing rates increase (Walters, 1998). This optimum water content, which maximizes seed longevity at a given temperature, is species specific. It appears to occur at a constant relative humidity for all species (Walters \& Engels, 1989). Therefore, understanding the relationship between the storage tempera-ture, relative humidity and seed water content is essential for developing optimal seed storage protocols (Merritt et al., 2003). Most seeds are hygroscopic, adsorbing or desorbing water until they are in equilibrium with the storage environment (Merritt et al., 2003). Water sorption isotherms describe the relationship between relative humidity and the equilibrium seed moisture content at a given temperature (Reuss \& Cassells, 2003). The exact nature of this relationship varies between different species as it is influenced by seed composition (Vertucci \& Leopold, 1987) and temperature (Eira et al., 1999). 
According to Vertucci \& Roos (1993) and Walters (1998) isotherms of orthodox seeds generally have the reverse sigmoidal shape, indicative of three regions of water binding or tissue water interactions. Desiccation intolerant species have the monotonic shaped or a simple rising curve (Vertucci \& Leopold 1987; Eira et al., 1999). Eira et al. (1999) have reported that the shape of isotherms of coffee seed tissues was intermediate to the reverse sigmoidal shape observed for orthodox seeds and the monotonic shape observed for desiccation intolerant plant tissues. Thus, coffee seeds are now considered to have storage behavior intermediate between recalcitrant and orthodox seeds (Ellis et al., 1991; Hong \& Ellis, 1995). Isotherms are also useful for analyzing seed water-binding properties (Merritt et al., 2003). The strength and nature of water binding in seeds is considered to influence the rate of deteriorative reactions (Vertucci \& Roos, 1990). Therefore, waterbinding characteris-tics may be a factor in the variation in seed longevity between different species, although any relationships between seed water-binding properties and storage behavior are yet to be resolved (Eira et al., 1999). Sorption isotherms can be used to estimate to which moisture content seed can be dried in a given climate (Thomsen \& Stubsgaard, 1998).

Garcinia kola (Heckel) belongs to the Guttiferrae family (Geeta et al., 2006). The species is a multi-purpose fruit tree producing fruits, seeds, roots and stem which are extensively used in Ghana, Nigeria and other West African countries for dental care in the form of chewing-sticks (Adu-Tutu et al., 1979). G. kola which is also known as 'bitter cola' is highly used for its medicinal purposes because of its anti-viral, anti-inflammatory, anti-diabetic, bronchio-dilator and antihepotoxic attributes. Fruit extracts from $G$. kola have proven effective at stopping Ebola virus replication in laboratory test (Wikipedia contributors, 2006). The trees are often felled to facilitate both removal of bark and harvest of chewing-sticks, contributing to the increasing scarcity of the species. The natural regeneration of the species is poor, and seedlings are uncommon and slowgrowing (Abbiw, 1990), making the species close to commercial extinction (Hawthorne, 1997).

Terminalia superba and T. ivorensis belong to the Combretaceae family (Irvine, 1961). Timber from the two species can be used for many purposes and are widely known and used, particularly in plywood manufacture, furniture, joinery, for plinths, mouldings, general fittings, and door faces and, after suitable treatment, for external joinery, flooring, furniture components and sliced veneer (Dupuy \& Mille, 1993).

Khaya anthotheca belongs to the Meliaceae family (Irvine, 1961). The species is heavily exploited, particularly in East and West Africa, and serves as a source of Africa mahogany, used in cabinet and furniture making, veneer, paneling, boat building and joinery (Irvine, 1961).

Entandrophragma angolense is also from the family, Meliaceae (Irvine, 1961). The commercial exploitation of this timber has resulted in the large-scale extinction of matured individual trees throughout its range. The timber is used for exterior and interior construction, furniture making and flooring.

Mansonia altissima is from the family 
Sterculiaceae (Irvine 1961). The timber is used for general and high-class joinery, cabinet work, furniture, decorative veneer and handicrafts. It is also used in construction for doors and windows, in railway coaches and shop fittings, and for boxes and crates (Ohene-Coffie, 2008). All the six species are listed in the IUCN Read List of Threatened Species (IUCN, 2008) and, thus, their ex-situ conservation is very important.

Developing water sorption isotherms of the species will be useful in interpreting the approximate relative humidity for their storage or drying and can be used to identify critical relative humidity. The objective of the study was to construct water sorption isotherms for the seeds of the six species so that the critical relative humidity for storage could be inferred to enhance their ex-situ conservation.

\section{Materials and methods \\ Seed material}

Fruits/seeds of $G$. kola, T. superba, $T$. ivorensis, M. altissima, E. angolense and $K$. anthotheca were collected at full maturity from wild populations from forest reserves in the Ashanti and Eastern regions of Ghana, between November and March 2005. Seeds were quickly processed and packed into cotton bags and sent by air to the Seed Conservation Department of the Royal Botanic Gardens, Kew, Wakehurst Place, UK, where experiments to generate water sorption isotherms for the species were conducted at a temperature of $20^{\circ} \mathrm{C}$. Seeds of $G$. kola were mixed with moistened sawdust before they were packed into cotton bags in order to maintain seed moisture as the species was suspected to possess the typical characteristics of desiccation sensitive seeds.
Moisture content and equilibrium relative humidity (eRH) of seeds

Prior to equilibrating seeds to the various moisture content, the initial seed moisture contents and equilibrium relative humidity (eRH) of seed samples of all the species were measured. Seed moisture content of the species was determined on whole seeds. Five replicates of five seeds each were weighed before and after drying at $103{ }^{\circ} \mathrm{C}$ for $17 \mathrm{~h}$ (ISTA, 2007). The moisture content was then calculated using the formula: (IW-FW)/ IW $\times$ 100 , where IW = initial weight, and $\mathrm{FW}=$ final weight. Seed equilibrium relative humidity at $20{ }^{\circ} \mathrm{C}$ was measured using a Rotronic AW-14P water activity measuring station (Rotronic Instruments, UK, Horley) set up with a DMS $100 \mathrm{H}$ humidity sensor. The essence of this experiment was to measure the relative humidity of air above the seed samples. This was to determine how dried seed samples were on receipt at the laboratory to facilitate post-harvest handling of the seeds (MSBP 2005).

\section{Equilibration of seeds}

Seeds were equilibrated over a series of lithium chloride $(\mathrm{LiCl})$ solutions, ranging in relative humidity from 12 to $93 \%$, and silica gel with $3 \%$ relative humidity at $20^{\circ} \mathrm{C}$. The relative humidity conditions (Table 1 ) were obtained by adding various weights of $\mathrm{LiCl}$ granules to $100 \mathrm{ml}$ of deionised water and stirred with a magnetic stirrer to mix (MSBP 2002). Once prepared, the solutions were allowed to equilibrate in sealed containers for $24 \mathrm{~h}$ at $20^{\circ} \mathrm{C}$. Storage glass jars were quarterfilled with the prepared $\mathrm{LiCl}$ solutions and appropriately labeled as recommended by Gold \& Hay (2007). The RH of $\mathrm{LiCl}$ salt solution were monitored using a hygrometer 
(a Rotronic AWVC-DIO sensor manufactured by Rotronic Ltd of the United Kingdom).

TABLE 1

Relative humidity series prepared using differing concentrations of lithium chloride to equilibrate seed samples at $20{ }^{\circ} \mathrm{C}$

$\begin{array}{lc}\text { Weight of LiCl granules }(g) & R H(\%) \text { generated } \\ \text { dissolved in } 100 \mathrm{ml} \text { of } & \text { at } 20^{\circ} \mathrm{C} \\ \text { deionised water } & \end{array}$

\begin{tabular}{cc}
\hline *Silica gel & 3 \\
90 & 12 \\
80 & 13 \\
70 & 18 \\
60 & 24 \\
50 & 33 \\
40 & 44 \\
30 & 60 \\
20 & 80 \\
10 & 90 \\
5 & 93 \\
\hline
\end{tabular}

* Silica gel was used to create RH of 3\%.

Seed samples to be equilibrated were placed in open dishes above the $\mathrm{LiCl}$ solutions on plastic supports. To hasten the equilibration of seed samples of $G$. kola, each seed was cut into two pieces due to their large sizes. The glass jars were sealed and seeds allowed to reach equilibrium. To determine when equilibrium point has been reached, seed sample weights were monitored for weight loss/gain every 2 days until there was no further change in weight. Samples were drawn for moisture contents determination gravimetrically by drying the seeds at $103{ }^{\circ} \mathrm{C}$ for $17 \mathrm{~h}$ (ISTA, 2007). The values of moisture contents were then plotted against relative humidity to construct moisture sorption isotherms (moisture-release curves) for the species using a SigmaPlot (SPW 8.0) software package.

\section{Results}

Seed species took different days to equilibrate depending on the seed size and structure. This ranged from 13 days for $E$. angolense to 91 days for $G$. kola at $20^{\circ} \mathrm{C}$.

\section{Water sorption in T. ivorensis seeds}

T. ivorensis seeds placed at relative humidities from 44 to $93 \%$ gained fresh weight whilst samples placed between 3 and $33 \%$ relative humidities lost fresh weight during the 30 days taken for all the seed samples to reach equilibrium (Table 3 ). The sorption curve shown in Fig. 2b established the fact that when moist $T$. ivorensis seed with initial moisture content of $18.5 \%$ (Table 2) was placed at the temperature of $20^{\circ} \mathrm{C}$ and $3 \% \mathrm{RH}$, the moisture content dropped to an equilibrium moisture content of $4.4 \%$. When placed at $20{ }^{\circ} \mathrm{C}$ and $60 \% \mathrm{RH}$, the moisture content settled at an equilibrium moisture content of $10.6 \%$, and at $20^{\circ} \mathrm{C}$ with $93 \% \mathrm{RH}$, the moisture content of the seed sample at equilibration was $22.9 \%$. The curve exhibited three zones. Seed water content

$$
\text { TABLE } 2
$$

Moisture content (\%) and equilibrium relative humidity (eRH) (\%) of seed samples prior to equilibration

\begin{tabular}{lcc}
\hline Seed species & $\begin{array}{c}\text { Moisture } \\
\text { content(\%) }\end{array}$ & $\begin{array}{c}\text { SeedeRH } \\
(\%)\end{array}$ \\
T. superba & 14.0 & 62 \\
T. ivorensis & 18.5 & 70 \\
K. anthotheca & 14.2 & 55 \\
E. angolense & 6.4 & 35 \\
M. altissima & 13.4 & 68 \\
G. kola & 58.0 & 97 \\
\hline
\end{tabular}


Asomaning et al.: Water sorption isotherm characteristics of six indigenous tree seeds

TABLE 3

Fresh weight changes of $\mathrm{T}$. ivorensis seed samples recorded during the first 30 days under various $R H$ chambers at $20^{\circ} \mathrm{C}$

\begin{tabular}{ccccccccc}
\hline & \multicolumn{7}{c}{ Relative humidity (\%) } \\
& 93 & 90 & 60 & 44 & 33 & 24 & 11 & 3 \\
\hline $\begin{array}{c}\text { Drying period(days) } \\
0\end{array}$ & 3.048 & 3.531 & 3.643 & 3.633 & 3.863 & 3.676 & 3.855 & 3.778 \\
3 & 3.332 & 3.808 & 3.711 & 3.657 & 3.793 & 3.590 & 3.648 & 3.571 \\
6 & 3.443 & 3.876 & 3.708 & 3.650 & 3.771 & 3.557 & 3.584 & 3.505 \\
9 & 3.440 & 3.870 & 3.708 & 3.652 & 3.769 & 3.554 & 3.581 & 3.498 \\
12 & 3.490 & 3.871 & 3.709 & 3.648 & 3.765 & 3.552 & 3.574 & 3.494 \\
18 & 3.462 & 3.874 & 3.703 & 3.644 & 3.761 & 3.547 & 3.567 & 3.486 \\
21 & 3.473 & 3.873 & 3.703 & 3.645 & 3.761 & 3.545 & 3.564 & 3.484 \\
24 & 3.476 & 3.861 & 3.698 & 3.622 & 3.756 & 3.542 & 3.562 & 3.480 \\
27 & 3.481 & 3.861 & 3.697 & 3.640 & 3.754 & 3.540 & 3.560 & 3.480 \\
30 & 3.471 & 3.854 & 3.694 & 3.637 & 3.755 & 3.538 & 3.558 & 3.477 \\
\hline
\end{tabular}

increased rapidly between 4 and 13\% RH, 11\% relative humidities lost fresh weight followed by a more gradual, linear increase in during the 31 days taken for all seeds to reach water content between 13 and about $80 \%$, and equilibration (Table 4). The sorption curve a final, rapid region of hydration above $80 \%$.

\section{Water sorption in T. superba seeds}

(Fig. 2a) indicated that when moist $T$. superba seed with initial moisture content of $14.0 \%$ (Table 2) was placed at $20^{\circ} \mathrm{C}$ and $3 \%$

Seeds of $T$. superba placed at relative humidities from 18 to $93 \%$ gained fresh weight whilst those placed between 3 and relative humidity, seed moisture dropped to an equilibrium moisture content of $3.9 \%$. When placed at $20{ }^{\circ} \mathrm{C}$ and $60 \%$ relative
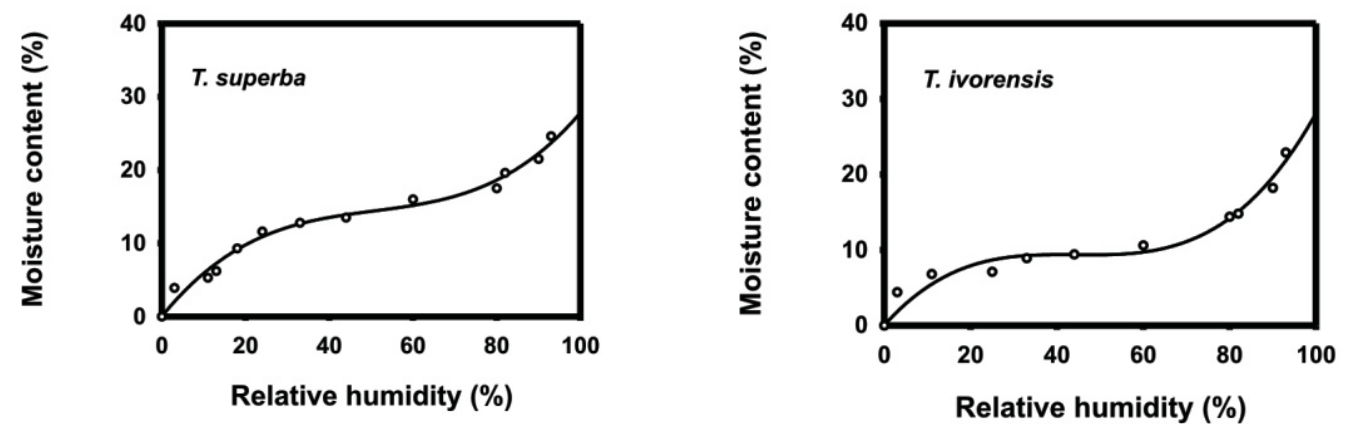

Fig. 1. Water sorption isotherms of T. superba (a) and T. ivorensis (b) seeds showing the relationship between the equilibrium moisture content and relative humidity at $20^{\circ} \mathrm{C}$ 
humidity, seed moisture content settled at an equilibrium moisture content of $16.0 \%$, and at $20{ }^{\circ} \mathrm{C}$ with $93 \%$ relative humidity, the moisture content of the seed at equilibration was $24.3 \%$. Sorption curve of T. superba also showed three zones. Seed water content increased rapidly between 3 and $20 \%$ relative humidities, followed by a more gradual, linear increase in water content between 20 and $60 \%$ relative humidities, and a final, rapid region of hydration above $80 \%$ relative humidity.

Water sorption characteristics of $K$. anthotheca seed

Seeds of $K$. anthotheca, placed in chambers with relative humidities from 60 to 93\% gained fresh weight whilst samples placed between 3 and $33 \%$, relative humidities lost fresh weight during the 15

TABLE 4

Fresh weight changes of T. superba seed samples recorded during the first 30 days of drying under various RH chambers $20^{\circ} \mathrm{C}$

\begin{tabular}{ccccccccc}
\hline & \multicolumn{7}{c}{ Relative humidity(\%) } & \\
& 93 & 90 & 80 & 60 & 33 & 18 & 11 & 3 \\
\hline Drying period (days) & & \multicolumn{7}{c}{ Seed samples weight(g) } \\
0 & 3.546 & 4.062 & 3.946 & 3.862 & 4.181 & 4.190 & 3.959 & 4.228 \\
3 & 3.949 & 4.506 & 4.283 & 4.118 & 4.310 & 4.229 & 3.859 & 3.940 \\
6 & 4.191 & 4.728 & 4.399 & 4.168 & 4.318 & 4.227 & 3.822 & 3.882 \\
9 & 4.193 & 4.735 & 4.399 & 4.163 & 4.321 & 4.227 & 3.819 & 3.876 \\
12 & 4.177 & 4.715 & 4.405 & 4.172 & 4.325 & 4.229 & 3.816 & 3.871 \\
15 & 4.211 & 4.748 & 4.411 & 4.178 & 4.323 & 4.225 & 3.812 & 3.868 \\
18 & 4.202 & 4.777 & 4.423 & 4.179 & 4.324 & 4.225 & 3.811 & 3.865 \\
21 & 4.242 & 4.808 & 4.429 & 4.184 & 4.326 & 4.226 & 3.810 & 3.865 \\
24 & 4.247 & 4.773 & 4.412 & 4.216 & 4.323 & 4.224 & 3.809 & 3.864 \\
27 & 4.237 & 4.753 & 4.422 & 4.206 & 4.323 & 4.224 & 3.809 & 3.863 \\
30 & 4.247 & 4.757 & 4.422 & 4.204 & 4.324 & 4.223 & 3.807 & 3.863 \\
\hline
\end{tabular}
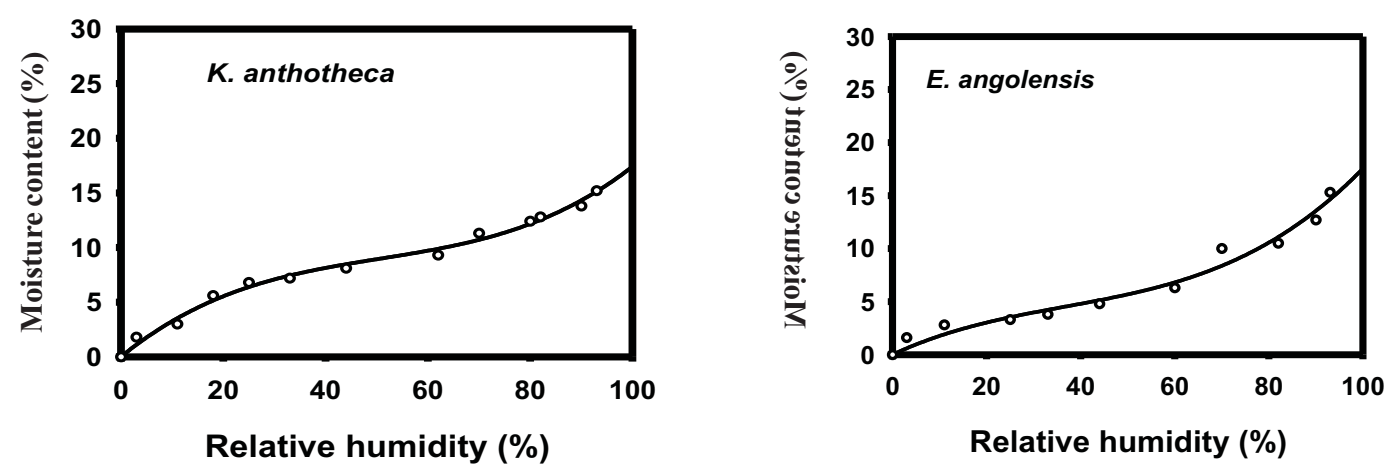

Fig. 2. Water sorption isotherms of $K$. anthotheca (a) and $E$. angolense (b) seeds showing the relationship between the equilibrium moisture content and relative humidity at $20^{\circ} \mathrm{C}$ 
days for all the seed samples to equilibrate (Table 5). When moist $K$. anthotheca seed with initial moisture content $14.2 \%$ (Table 2) was placed at an environment with temperature $20{ }^{\circ} \mathrm{C}$ and $3 \%$ relative humidity, the moisture content dropped at an equilibrium moisture content of $1.8 \%$. When placed at $20{ }^{\circ} \mathrm{C}$ and $60 \%$ relative humidity, the moisture content rose to an equilibrium moisture content of $9.3 \%$. Seeds placed in chambers of $93 \%$ relative humidity, at $20{ }^{\circ} \mathrm{C}$ the moisture content continued to increase to an equilibration of $15.9 \%$. The sorption curve showed three regions or zones. Water content increased rapidly between 3 and $25 \%$ relative humidities, followed by a more gradual, linear increase in water content between 25 and about $70 \%$, and a final, rapid region of hydration above $75-80 \%$ (Fig. 2a).

\section{Water sorption in E. angolense seeds}

Seeds of $E$. angolense, which were placed in chambers with relative humidities from 70 to $93 \%$, gained fresh weight whilst samples placed in chambers with relative humidities between 3 and $60 \%$ lost fresh weight during the period of the experiment, which lasted for about 13 days for all the seed samples to equilibrate. The sorption curve (Fig. 2b) indicated that moist $E$. angolense seeds with initial moisture content $6.4 \%$ (Table 2), placed at an environment with a temperature of $20{ }^{\circ} \mathrm{C}$ and $3 \%$ relative humidity had their moisture content dropped to an equilibrium moisture content of $1.6 \%$. On the other hand, at $20{ }^{\circ} \mathrm{C}$ and relative humidity of $60 \%$ seed moisture content settled at an equilibrium moisture content of $6.3 \%$. At $20^{\circ} \mathrm{C}$ with $93 \%$ relative humidity, the moisture content of the seed sample at equilibration was $15.3 \%$. The curve showed three zones with water content increasing rapidly between 3 and 25\% relative humidity, followed by a more gradual, linear increase in water content between 25 and about $80 \%$, and a final, rapid region of hydration above $80 \%$.

Water sorption attributes of $M$. altissima seeds

Seeds placed in chambers with relative humidities from 70 to $93 \%$ gained fresh weight whilst samples placed between 3 and $60 \%$ relative humidities lost fresh weight during the experimental period which lasted

TABLE 5

Fresh weight changes of $K$. anthotheca seed samples recorded during the first 15 days under various $R H$ chambers at $20^{\circ} \mathrm{C}$

\begin{tabular}{cccccccccc}
\hline & 93 & \multicolumn{7}{c}{ Relative humidity (\%) } \\
& 90 & 80 & 60 & 33 & 18 & 11 & 3 \\
\hline Drying period (days) & \multicolumn{8}{c}{ Seed samples weight(g) } \\
0 & 1.375 & 1.315 & 1.268 & 1.419 & 1.323 & 1.100 & 1.421 & 1.252 \\
3 & 1.444 & 1.374 & 1.311 & 1.447 & 1.320 & 1.085 & 1.3512 & 1.185 \\
6 & 1.481 & 1.397 & 1.329 & 1.454 & 1.320 & 1.084 & 1.3461 & 1.173 \\
9 & 1.507 & 1.408 & 1.336 & 1.457 & 1.320 & 1.084 & 1.3455 & 1.166 \\
12 & 1.511 & 1.409 & 1.336 & 1.457 & 1.319 & 1.083 & 1.3451 & 1.166 \\
15 & 1.510 & 1.409 & 1.336 & 1.457 & 1.319 & 1.083 & 1.3451 & 1.166 \\
\hline
\end{tabular}


TABLE 6

Fresh weight changes of $E$. angolense seed samples recorded during the first 13 days under various $R H$ chambers $20^{\circ} \mathrm{C}$

\begin{tabular}{ccccccccc}
\hline & \multicolumn{7}{c}{ Relative humidity (\%) } \\
& 93 & 90 & 80 & 70 & 60 & 18 & 11 & 3 \\
\hline Drying period (days) & & \multicolumn{7}{c}{ Seed samples weight(g) } \\
0 & 1.591 & 1.603 & 1.482 & 1.432 & 1.703 & 1.572 & 1.652 & 1.475 \\
1 & 1.659 & 1.648 & 1.574 & 1.468 & 1.696 & 1.561 & 1.606 & 1.467 \\
2 & 1.751 & 1.674 & 1.607 & 1.485 & 1.693 & 1.554 & 1.598 & 1.459 \\
3 & 1.745 & 1.702 & 1.605 & 1.502 & 1.692 & 1.555 & 1.594 & 1.454 \\
4 & 1.760 & 1.709 & 1.599 & 1.505 & 1.692 & 1.555 & 1.594 & 1.452 \\
5 & 1.785 & 1.715 & 1.602 & 1.507 & 1.692 & 1.552 & 1.593 & 1.452 \\
6 & 1.796 & 1.719 & 1.603 & 1.508 & 1.692 & 1.552 & 1.593 & 1.451 \\
7 & 1.803 & 1.721 & 1.603 & 1.509 & 1.692 & 1.554 & 1.593 & 1.450 \\
8 & 1.808 & 1.723 & 1.602 & 1.509 & 1.691 & 1.554 & 1.593 & 1.450 \\
9 & 1.810 & 1.724 & 1.603 & 1.509 & 1.691 & 1.551 & 1.592 & 1.449 \\
10 & 1.811 & 1.724 & 1.603 & 1.510 & 1.691 & 1.551 & 1.592 & 1.449 \\
11 & 1.816 & 1.724 & 1.599 & 1.508 & 1.691 & 1.551 & 1.591 & 1.448 \\
12 & 1.816 & 1.724 & 1.599 & 1.510 & 1.691 & 1.551 & 1.590 & 1.447 \\
13 & 1.816 & 1.724 & 1.603 & 1.510 & 1.691 & 1.551 & 1.590 & 1.447 \\
\hline
\end{tabular}

for about 30 days for all the seed samples to equilibrate (Table 7). Humidity had the moisture content dropped seeds with initial moisture content of $13.4 \%$ ( Table 2) placed in an environment with a temperature of $20^{\circ} \mathrm{C}$ and $3 \%$ relative humidity to an equilibrium moisture content of $5.3 \%$. Seeds of the species placed in an environment at $20^{\circ} \mathrm{C}$ and $60 \%$ relative humidity had the moisture content settled at equilibrium moisture content of $10.3 \%$. On the other hand, seed samples of the species placed in an environment of $20{ }^{\circ} \mathrm{C}$ with $93 \%$ relative humidity had their moisture content at equilibration to be $30.8 \%$. The sorption curve of $M$. altissima showed three regions or zones. Water content increased rapidly between 3 and $20 \%$ relative humidity followed with a gradual, linear increase in water content between 20 and $80 \%$, and a final rapid region of hydration above $80 \%$.
Water sorption in G. kola seeds

Seeds placed at all relative humidities from 3 to $93 \%$ lost fresh weight during the period of the experiment which lasted for about 91 days for all the seed samples to reach equilibration (Table 8). Samples weight loss was generally slow but this was more pronounced in samples dried under high relative humidity regimes.

The sorption curve showed that when moist G. kola seeds with initial moisture content $58.0 \%$ (Table 2) was placed at $20{ }^{\circ} \mathrm{C}$ and $3 \%$ relative humidity, the moisture content of the seeds dropped to an equilibrium moisture content of $4.2 \%$ and when placed at $93 \%$, the moisture content settled at $21.8 \%$. At a relative humidity of $66 \%$ the seed moisture content settled at $12.2 \%$ (Fig. 3b). Seed deterioration, manifested by fungal growth, was observed as relative humidity of the drying 
TABLE 7

Fresh weight changes of $M$. altissima seed samples recorded during the first 15 days under various $R H$ chambers at $20^{\circ} \mathrm{C}$

\begin{tabular}{ccccccccc}
\hline & \multicolumn{7}{c}{ Relative humidity (\%) } \\
& 93 & 90 & 82 & 70 & 60 & 18 & 11 & 3 \\
\hline Drying period (days) & & \multicolumn{7}{c}{ Seed sample weight(g) } \\
0 & 3.136 & 3.224 & 3.062 & 3.249 & 3.077 & 3.156 & 3.103 & 3.068 \\
1 & 3.203 & 3.268 & 3.082 & 3.281 & 3.045 & 3.112 & 3.016 & 2.974 \\
2 & 3.256 & 3.297 & 3.095 & 3.303 & 3.025 & 3.084 & 2.974 & 2.922 \\
3 & 3.303 & 3.320 & 3.101 & 3.315 & 3.009 & 3.064 & 2.946 & 2.890 \\
4 & 3.311 & 3.325 & 3.103 & 3.318 & 3.007 & 3.060 & 2.940 & 2.884 \\
5 & 3.347 & 3.343 & 3.110 & 3.329 & 2.997 & 3.047 & 2.922 & 2.865 \\
6 & 3.383 & 3.364 & 3.117 & 3.341 & 2.988 & 3.036 & 2.907 & 2.848 \\
7 & 3.421 & 3.383 & 3.123 & 3.353 & 2.980 & 3.025 & 2.893 & 2.838 \\
8 & 3.456 & 3.402 & 3.128 & 3.363 & 2.974 & 3.017 & 2.881 & 2.820 \\
9 & 3.485 & 3.412 & 3.132 & 3.372 & 2.968 & 3.010 & 2.872 & 2.801 \\
10 & 3.515 & 3.427 & 3.135 & 3.382 & 2.962 & 3.004 & 2.861 & 2.799 \\
11 & 3.569 & 3.438 & 3.139 & 3.390 & 2.959 & 2.999 & 2.856 & 2.793 \\
12 & 3.620 & 3.480 & 3.152 & 3.414 & 2.950 & 2.988 & 2.842 & 2.776 \\
13 & 3.638 & 3.490 & 3.152 & 3.418 & 2.948 & 2.986 & 2.838 & 2.772 \\
14 & 3.656 & 3.499 & 3.154 & 3.422 & 2.946 & 2.983 & 2.829 & 2.767 \\
15 & 3.674 & 3.510 & 3.156 & 3.426 & 2.943 & 2.981 & 2.825 & 2.763 \\
\hline
\end{tabular}

environment increased. At 90\% and 93\% relative humidities, which were very moist, all seeds deteriorated before reaching equilibrium. The curve is divided into three zones. Water content increased rapidly between 3 and $25 \%$ relative humidity, followed by a gradual, linear increase in water content between 25 and $80 \%$, and a final, rapid region of hydration above $80 \%$.

\section{Discussions}

Conservation of genetic resources of forest trees in Africa is a challenging task because of limited information available. In seed gene banks, temperature and relative humidity are the most prominent factors determining seed water content and, therefore, directly influence seed longevity during storage
(Walters, 1998; Vertucci \& Roos, 1993). The importance of these factors made it essential to understand the interaction among storage parameters in order to develop optimal seed storage protocols. Seeds are generally hygroscopic and will equilibrate according to the water potential gradient between the seed and the surrounding air. Lowering the relative humidity or increasing the temperature decreases the water potential of the air, thus, there is a net water movement out of the seeds and lower water content is reached(Walters, 1998)

In the present study, moisture sorption isotherm curves were developed for the species under consideration in order to study the behaviour of water in their tissues (Baldet et al., 2008). G. kola seed samples placed at 
TABLE 8

Fresh weight changes of $G$. kola seed samples recorded during the first 30 days of drying under various $R H$ chambers at $20^{\circ} \mathrm{C}$

\begin{tabular}{|c|c|c|c|c|c|c|c|c|}
\hline \multicolumn{9}{|c|}{ Relative humidity (\%) } \\
\hline & 93 & 83 & 66 & 44 & 33 & 26 & 15 & 3 \\
\hline Drying period (days) & \multicolumn{8}{|c|}{ Seed samples weight(g) } \\
\hline 0 & 8.831 & 9.526 & 7.387 & 7.927 & 8.746 & 7.776 & 7.007 & 9.857 \\
\hline 3 & 8.805 & 9.475 & 7.090 & 7.605 & 8.428 & 7.495 & 6.592 & 9.371 \\
\hline 6 & 8.777 & 9.427 & 7.050 & 7.392 & 8.307 & 7.295 & 6.057 & 8.887 \\
\hline 9 & 8.744 & 9.368 & 6.956 & 7.046 & 8.146 & 6.766 & 5.388 & 8.253 \\
\hline 12 & 8.689 & 9.291 & 6.896 & 6.612 & 7.910 & 6.144 & 5.013 & 7.509 \\
\hline 15 & 8.608 & 9.202 & 6.779 & 6.164 & 7.624 & 5.607 & 4.775 & 6.467 \\
\hline 18 & 8.522 & 9.123 & 6.560 & 5.815 & 7.365 & 5.358 & 4.661 & 5.684 \\
\hline 21 & 8.389 & 9.045 & 6.233 & 5.552 & 7.131 & 5.227 & 4.588 & 5.313 \\
\hline 24 & 8.108 & 8.942 & 5.805 & 5.300 & 6.841 & 5.115 & 4.524 & 5.010 \\
\hline 27 & 8.091 & 8.849 & 5.635 & 5.214 & 6.707 & 5.076 & 4.499 & 4.950 \\
\hline 30 & 8.065 & 8.643 & 5.329 & 5.108 & 6.453 & 5.013 & 4.459 & 4.850 \\
\hline
\end{tabular}

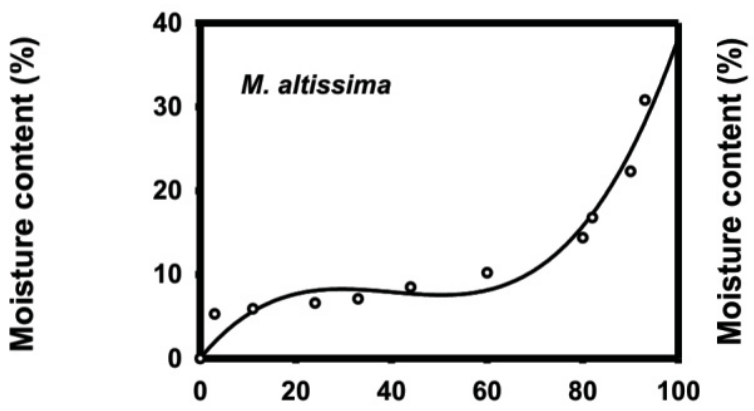

Relative humidity (\%)

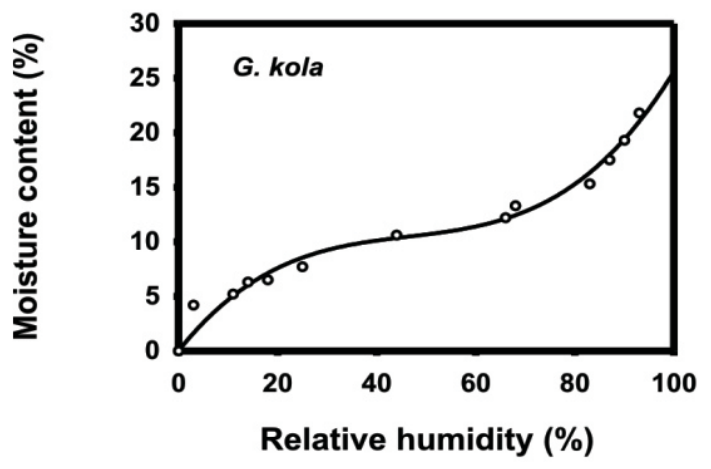

Fig. 3. Water sorption isotherms of M. altissima (a) and G. kola (b) seeds showing the relationship between the equilibrium moisture content and relative humidity at $20^{\circ} \mathrm{C}$.

all relative humidity from $3 \%$ to $93 \%$ lost fresh weight. This implies that there was a net loss of seed moisture (desorption) to the environment. This observation can be explained by the fact that all seeds are hygroscopic and automatically absorb or desorb moisture by diffusion along a water potential gradient between the seed and the surrounding air. If the water potential of the seed is greater than the surrounding air, the seed will lose water and become drier (Probert, 2003). In this sense, G. kola seeds placed at all relative humidities lost moisture to their environments due to their initial high moisture content and eRH (Table 2). Hence, their greater water potential than the water potential in the environment.

Seeds of $T$. superba, T. ivorensis, $K$. anthotheca, E. angolense and M. altissima placed in the various relative humidity 
chambers either lost weight (desorption) or gained weight (adsorption) depending on the relative chambers they were placed in and the water potential of the seeds in those chambers. Seeds of T. superba, T. ivorensis, $K$. anthotheca, E. angolense and M. altissima placed in relative humidity chambers with higher RHs gained fresh weights due to water gain (adsorption) from their environments as a result of the seeds low water potential. On the other hand, seeds of these species placed in lower relative humidity chambers lost fresh weights (desorption) due to movement of water from the seeds into their respective environments (Probert, 2003).

The moisture sorption isotherms curves generated for the species showed that seed moisture content increases with increasing relative humidity. Moisture sorption isotherm curves of $T$. superba, T. ivorensis, $E$. angolense, $K$. anthotheca and $M$. altissima have been divided into three regions. The three regions of an isotherm curve have been classified by the strength which water is bound to tissues in seeds and the nature of the binding site: water which is tightly bound to ionic groups (Region 1), weakly bound to polar nonionic sites (Region 2), multilayer molecular sorption sites (Region 3) (Rupley et al., 1983; Sun, 2002). The strong water -binding tissues account for the steep portion of sorption curves at very low humidity levels. There are thought to be hydrophilic surfaces within seeds that bind water very tightly and, thus, strongly resist dehydration. The interaction of water with the weak waterbinding tissues is thought to cause the relatively flat, middle portion of sorption curves. This represents the interaction of water with the less hydrophilic and the more hydrophobic surfaces within the seed (Moravec et al., 2008).
When all the strong and weak hydration sites of the tissues within the seed are saturated with water, the slope of the sorption curve increases sharply. The steep portion of the sorption curve represents the activity of multilayer molecular sorption sites, meaning that water begins to form multiple layers on surfaces within the seed by binding to itself through cohesive forces (Moravec et al., 2008). In the present study, the isotherms for T. superba, T. ivorensis, E. angolense, $K$. anthotheca and $M$. altissima are consistent with those of native species of Australia generated by Merritt et al. (2003). They exhibited a reverse sigmoidal shape characteristic of orthodox species as reported by McDonald \& Copeland (1996), but they varied from species to species due to differences in composition (Vertucci \& Leopold, 1987; Vertucci \& Roos, 1993). The curves have inflection points at approximately $13-25 \% \mathrm{RH}$ for the boundary of sorption zones 1 and 2, and another at 60$80 \% \mathrm{RH}$ for the boundary of sorption zones 2 and 3 at $20^{\circ} \mathrm{C}$.

The shape of moisture sorption isotherm curve of G. kola

The fact that G. kola trees are often found in humid ecosystems, the fact that the fruits/seeds are shed at the time when they have very high moisture content (Agyili et al., 2007), fruits and seed are large and fleshy (Thomsen, 2000), and seed viability of the species reduces drastically when seed moisture content falls below 30\% (Agyili et al., 2007), among others, are points which place G. kola, into the desiccation intolerant (desiccation sensitive) category, so far as seed storage physiology is concerned.

According to Vertucci \& Leopold (1987) in the desiccation intolerant condition, 
isotherms are more hyperbolic, indicating that the water binding differs between plant tissues that are intolerant versus those that are tolerant to desiccation. Isotherm of a hyperbolic form (monotonic isotherms) has also been reported for a sampling of recalcitrant seeds, including cacoa and acorn (Leopold \& Vertucci, 1986). According to the Langmuir sorption theory, these monotonic isotherms indicate that there is little or no contribution to the water absorption characteristics by the strong binding sites (Atkins, 1982).

In the present study, however, the shape of the sorption isotherm developed for G. kola, described as recalcitrant by Agyili et al. (2007), exhibited the sigmoidal character which is typical of desiccation tolerant species (Vertucci \& Leopold, 1987). There is no information on the maturity stages of the cacoa and acorn seeds used by Vertucci \& Leopold (1987) to develop the isotherms for the two species, which the authors described as hyperbolic in shape. The stage of maturity of seeds has a marked effect on the level of desiccation sensitivity (Finch-Salvage \& Blake, 1994). Immature seed tissues tend to be more desiccation intolerant than mature tissues of the same species (Aldridge \& Probert, 1993). In the present study, G. kola seeds which were used in developing the isotherm curve were fully matured. This probably may have influenced the shape of the curve. Another possible reason for the contradiction between the shapes of the isotherm developed for G. kola, on the one hand, in the present study and that for cacoa and acorn as observed by Leopold \& Vertucci (1986) is that, probably, not all desiccation intolerant species possess strong binding sites that do not contribute to water absorption as proposed by Langmuir sorption theory.
Probably, in the tissues of G. kola seeds, the strong binding sites contribute strongly in water absorption just like it occurs in the tissues of desiccation tolerant species. Kapseu et al. (2006) observed that sheanut kernels ( $V$. paradoxa), which also have recalcitrant storage behavior, lost viability below 20\% moisture content (Gaméné et al., 2004), showing the typical sigmoid shape curve similar to that of orthodox species and the curve developed for G. kola in the present study.

The results of this study show that water sorption properties of $T$. superba, $T$. ivorensis, M. altissima, E. angolense and $K$. anthotheca are generally similar to those of other orthodox species, suggesting that established storage methods for orthodox seeds may be applicable to these. Contrarily to what has been reported by other workers, sorption isotherm for G. kola (a desiccation sensitive species) also showed a sigmoidal relationship between seed water content and relative humidity similar to what was reported by Kapseu et al. (2006) for Vitellaria paradoxa, another desiccation sensitive species. This means that not all desiccation sensitive species exhibit the monotonic shaped or a simple rising curve.

\section{Conclusion}

The equilibrium relationship between water content, relative humidity at $20^{\circ} \mathrm{C}$ for seeds of Garcinia kola, Terminalia superba, Terminalia ivorensis, Mansonia altissima, Entandrophragma angolense and Khaya anthotheca have been described. Isotherms of the species studied exhibited the reversed sigmoidal shape characteristic of many macromolecules and indicative of the three regions of water binding. Water sorption- 
desorption characteristics for the species studied are comparable to isotherms of other seed species.

\section{Acknowledgement}

The author thanks the UK Government and the Commonwealth Scholarship Commission for funding the study through the Commonwealth Fellowship Programme. This study was carried out at the Seed Conservation Department of the Royal Botanic Gardens, Kew, Wakehurst Place. Many thanks go to the management and staff for their kind support in the laboratory.

\section{References \\ Abbiw D. K. (1990). Useful plants of Ghana. Intermediate Technology Publications and Royal Botanic Gardens, Kew, London, 337 pp.}

Adu-Tutu M., Afful L. Y., Asante-Appiah K. Lieberman D., Hall J. B. and Elvin-Lewis M. (1979). Chewing stick usage in Ghana. Econ. Bot. 33: 320-328.

Agyili J., Sacande M., Koffi E.and Peprah T. (2007) Improving the collection and germination of West African Garcinia kola Heckel seeds. New Forests 34: 269-279.

Aldridge C. D, and Probert R. J. (1993). Seed development the accumulation of abscisic acid and desiccation tolerance in aquatic grasses Porteresia coarctata (Ruxb). Tateoka and Oryza sativa L. Seed Sci. Res. 3: 97-103.

Atkins P. W. (1982). Physical Chemistry. W. H. Freeman, San Francisco, 1095 pp.

Baldet P., Colas F., and Bettez M. (2008). Measurement of water activity in forest tree seeds: an efficient tool for seed bank management. ISTA, FTS Workshop, Verona, Italy. 13 pp.

Daws M. I., Gaméné S. C., Sacande M., Pritchard H. W., Groot P. C. G. and Hoekstra F. (2004). Desiccation and storage of Lannea microcarpa seeds from Burkina Faso. In Comparative Storage Biology of Tropical Tree Seed. (M. Sacande, D. Joker, M. E. Dulloo and K. Thomsen, eds), pp. 36-39. IPGRI, Rome,

Dupuy B., Mille G. (1993). Timber plantations in the humid tropics of Africa. FAO Forestry Paper No. 98.

Eire M. T. S., Walters C. and Caldas L. S. (1999). Water sorption properties in Coffea spp. seed and embryo. Seed Sci. Res. 9: 321-330.

Ellis R. H., Hong T. D. and Roberts E. H (1991). An intermediate category of seed storage behavior? II. Effect of provenance, immaturity and imbibitions on desiccation-tolerance in coffee. J. Exp. Bot. 42: 653-657.

Finch-Savage W. E. and Blake P. S. (1994). Indeterminate devolpment in desiccation-sensitive seeds of Quercus robur L. Seed Sci. Res. 4: 127-133.

Gaméné C. S., Pritchard. H. W. and Daws M. I. (2004). Effect of desiccation and storage on Vitellaria paradoxa seed viability. In Comparative storage, biology of tropical tree seeds. (M. Sacandé, D, Joker, M. E. Dulloo and K. A. Thomsen, eds), pp. 57-66. IPGRI, Rome, Italy.

Geeta J. Kumar A. H. Balakrishna G and Srinivasa Y. B. (2006). Production of supernumerary plants from seed fragments in Garcinia gummi - gutta: evolutionary implications of mammalian frugivory. Current Sci. 91 (3).

Gold K. and Hay F (2007). Equilibrating seeds to specific moisture levels. Technical Information Sheet 09. Millennium Seed Bank Project. Kew, UK. (www.kew.org.msbp).

Hawthorne, W.D. (1979). Garcina kola. In 2004 IUCN Red List of Theatened Species. IUCN 2004.

Hong T. D. and Ellis R. H. (1995). Interspecific variation in seed storage behaviour within two genera - coffea and citrus. Seed Sci. Technol. 23: 165-181.

Irvine F. A. R. (1961). Woody plants of Ghana with special reference to their uses. Oxford Univ. Press, London, $146 \mathrm{pp}$.

The World Conservation Union (2008).2008 Red list of threatened species. IUCN 2008. (Available at www.iucnredlist.org)

Kapseu C., Nkouam G. B., Dirand M., Barth D., Perrin L. and Tchiegang C. (2006). Water vapour sorption isotherms of sheanut kernels (Vitellaria paradoxa Gaertn.) J. Fd Technol.4 (4): 235-241.

Leopold A. C., Vertucci and C. V. (1986). Physical attributes of desiccated seeds. In Membranes, Metabolism and Dry Organisms. (A. C. Leopold, ed.), pp 22-34. Cornell University Press, Ithaca, 
NY.

Medonald M. B. and Copeland L. (1997). Seed production: principles and practices. Chapman and Hall. New York, N.Y. 749 pp.

Merritt D. J., Touchell D. H., Senaratna T., Dixon K. W. and Sivasithamparam, K. (2003). Water sorption characteristics of seeds of four Western Australian species. Aust. J. Bot. 51: 85-92.

Moravec C. M., Bradford K. J. and Laca, E. A. (2008). Seed Sci. Technol. 36:311-324.

MSBP (Millennium Seed Bank Project) (2005). Post harvest handling. Technical Information Sheet 4. Royal Botanic Gardens, Kew, UK .

(MSBP) Millennium Seed Bank Project (2002). Seed conservation technique course. Handout, 9th -20 th September 2002. Royal Botanic Gardens, Kew, UK

Ohene-Coffie F. (2008). In Mansonia altissima (A. Chev, D. Louppe, A. A. Oteng-Amoako and M. Brink, eds.). Prota 7(1): Timbers/Bois d'œuvre 1. [CD-Rom]. PROTA, Wageningen, Netherlands.

Probert J. ( 2003). Seed viability under ambient conditions and the importance of drying. In Seed conservation: turning science into practice Chapter 19. (R. D. Smith, J. B. Dickie, S. H. Linington, H. W., Pritchard and J. B. Probert, eds.). R.B.G., Kew, UK.

Reuss R. and Cassells J. (2003). The effect of storage conditions on the quality of Australian canola (rapeseed) Brassica napus L. In Advances in stored product protection. (P. F. Creland, D. M. Armitage,
C. H. Bell, P.M. and Cogan, E. Highley, eds.), pp 498-503. Wallingford, Oxon, CAB. International.

Rupley J. A., Gratton E. and Careri, G. (1983). Water and globular proteins. Trends Biochem. Sci. 8: $18-22$.

Sun W. Q. (2000). Methods for studying water relations under stress. In Desiccation and Survival in Plants: Drying without Dying, (M. Black and H. W. Pritchard, eds.), pp. 47-91. CABI Publishing. New York, N.Y.

Thomsen K. ( 2000). Handling of desiccation and temperature sensitive tree seeds. Technical Note No. 56. Danida Forest Seed Centre. Humlebaek, Denmark. 30 pp.

Thomsen K. and Stubsgaard F (1998). Easy guide to controlling seed moisture during seed procurement. Lecture Note C - 5 A. Danida Forest Seed Centre, Denmark pp. 1-24.

Vertucci C. W. and Leopold A. C. (1987). Water binding in legume seeds. Pl. Physiol. 85: 224-231.

Vertucci C. W. and Roos, E. E. (1990). Theoretical basis of protocols for seed storage. Pl. Physiol. 94 1019-1023.

Vertucci C. W. and Roos E. E. (1993). Theoretical basis of protocols for seed storate II. The influence of temperature of optimal moisture levels. Seed Sci. Res. 3: 201-213.

Wikipedia Contributors (2006). http://en. Wikipedia.org/wiki/garcinia. 